\title{
Feasibility and acceptability of insecticide treated plastic sheeting (ITPS) for vector control in Papua New Guinea
}

\author{
Justin Pulford ${ }^{1,2}$, Anthony Tandrapah¹, Jo-An Atkinson², Brown Kaupa', Tanya Russell ${ }^{3}$, Manuel W Hetzel ${ }^{1,2^{*}}$ \\ From Challenges in malaria research \\ Basel, Switzerland. 10-12 October 2012
}

\section{Background}

This study assessed the feasibility and acceptability of utilising insecticide treated plastic sheeting (ITPS) as a malaria control intervention in Papua New Guinea (PNG).

\section{Method}

Zero Vector ${ }^{\circledR}$ ITPS was installed in 40 homes across four study sites representing a cross section of malaria transmission risk and housing style. Structured questionnaires were completed at the time of ITPS installation $(n=40)$ and at four weeks post installation $(\mathrm{n}=40)$ with the household head. Similarly, focus group discussions (FGDs) with the male and/or female household heads were completed at installation $(n=5)$ and four week follow-up $(n=4)$.

\section{Results}

ZeroVector ${ }^{\circledR}$ ITPS was successfully installed in a range of homes employing traditional and/or modern building materials in PNG. The ITPS installations remained intact over the course of the four week trial period and were highly acceptable to both male and female household heads. No dissatisfaction with the ITPS product was reported at four week follow-up; however, the installation process was time consuming, participants reported a reduction in mosquito net use following ITPS installation and many participants expressed concern about the longevity of ITPS over the longer term.

\section{Conclusion}

ZeroVector ${ }^{\circledR}$ ITPS installation is feasible and highly acceptable in a diverse range of PNG contexts and is likely to be

${ }^{1}$ Papua New Guinea Institute of Medical Research, Goroka, EHP 441, Papua New Guinea

Full list of author information is available at the end of the article favourably received as a vector control intervention if accessible en masse. A longer-term evaluation is required before firm policy or public health decisions can be made regarding the potential application of ITPS in the national malaria control program. The positive study findings suggest a longer-term evaluation of this promising malaria control intervention warrants consideration.

\section{Author details}

'Papua New Guinea Institute of Medical Research, Goroka, EHP 441, Papua New Guinea. ${ }^{2}$ The University of Queensland, School of Population Health, Herston, QLD 4006, Australia. ${ }^{3}$ James Cook University, Faculty of Medicine, Health and Molecular Sciences, Cairns, Australia.

Published: 15 October 2012

doi:10.1186/1475-2875-11-S1-P110

Cite this article as: Pulford et al:: Feasibility and acceptability of insecticide treated plastic sheeting (ITPS) for vector control in Papua New Guinea. Malaria Journal 2012 11(Suppl 1):P110.

Submit your next manuscript to BioMed Central and take full advantage of:

- Convenient online submission

- Thorough peer review

- No space constraints or color figure charges

- Immediate publication on acceptance

- Inclusion in PubMed, CAS, Scopus and Google Scholar

- Research which is freely available for redistribution

Submit your manuscript at www.biomedcentral.com/submit
() Biomed Central

\section{Biomed Central}

